\title{
AKIBAT HUKUM DARI PERKAWINAN DI BAWAH TANGAN (STUDI KASUS PUTUSAN NOMOR 40/PDT.P/2018/PA.WSB
}

\author{
Misbahul Huda \\ Sekolah Tinggi Ilmu Hukum IBLAM \\ Kramat Raya No.25, Senen, Jakarta Pusat \\ Email : misbahhuda464@gmail.com
}

$\begin{array}{ll}\text { Submisson } & : 6 \text { Agustus } 2021 \\ \text { Accepted } & : \text { 10 september 2021 } \\ \text { Publish } & : \text { 30 September 2021 }\end{array}$

\begin{abstract}
Marriage is one of the sacred covenants of a man with a woman to form a happy family. Marriage is a sacred thing because marriage is the beginning of building a household. In Indonesia, marriage has been regulated in Law Number 16 of 2019 concerning Amendments to Law Number 1 of 1974 concerning Marriage. prove that marriage is important in society. Everyone who wants to get married must meet the requirements that have been determined by law such as age limit, the marriage must be of the same religion and the marriage is recorded. The goal is that every marriage does not violate applicable norms and is also administratively orderly. The formulation of the problem: 1). What are the legal consequences of underhanded marriage? And what is the basis for the consideration of the Panel of Judges in deciding case number 40/Pdt.P/2018/PA.Wsb? The research method of this thesis is normative juridical, meaning that the issues raised, discussed and described in this research is focused on applying the rules or norms in positive law. In this study, the legal consequences of underhanded marriages, even though they are considered valid in religion or belief, are marriages conducted outside the knowledge and supervision of the marriage registrar, and do not have permanent legal force and are considered invalid in the eyes of state law. The legal consequences of marriage, one of which results when children enter school age when registered, every educational institution always requires the registrant (children's parents) one of which is a birth certificate. The requirement to make a child's birth certificate is a marriage book and the person who has a marriage book is the person who when holding the marriage contract registers his marriage.
\end{abstract}

Keywords: Marriage, Siri Wedding, Invite Marriage

\begin{abstract}
Abstrak
Perkawinan salah satu perjanjian suci seorang laki-laki dengan perempuan untuk membentuk keluarga bahagia. Perkawinan merupakan satu hal yang sakral karena perkawinan merupakan awal membangun rumah tangga. Di Indonesia perkawinan telah diatur dalam Undang-Undang Nomor 16 Tahun 2019 Tentang Perubahan Atas UndangUndang Nomor 1 Tahun 1974 Tentang Perkawinan. membuktikan bahwa perkawinan merupakan hal penting di masyarakat. Setiap
\end{abstract}


orang yang ingin menikah harus memenuhi persyaratan yang telah di tentukan oleh Undang-Undang seperti batas umur, perkawinan tersebut harus seagama dan perkawinan tersebut dicatat. Tujuannya agar setiap perkawinan tidak melanggar norma-norma yang berlaku dan juga tertib administrasi. Rumusan masalah: 1).Bagaimana Akibat hukum dari perkawinan di bawah tangan?Dan Bagaimana dasar pertimbangan Majelis Hakim dalam memutuskan perkara nomor 40/Pdt.P/2018/PA.Wsb?Metode penelitian skripsi ini adalah Yuridis Normatif, artinya permasalahan yang diangkat, dibahas dan diuraikan dalam penelitian ini difokuskan dengan menerapkan kaidah-kaidah atau norma-norma dalam hukum positif. dalam penelitian ini akibat hukum dari perkawinan di bawah tangan, meski secara agama atau kepercayaan dianggap sah, namun perkawinan yang dilakukan di luar pengetahuan dan pengawasan pegawai pencatat nikah tidak memiliki kekuatan hukum tetap dan dianggap tidak sah di mata hukum negara. Akibat hukum perkawinan tersebut salah satunya berakibat ketika anak memasuki usia sekolah ketika didaftarkan, setiap lembaga pendidikan selalu mensyaratkan kepada pendaftar (orang tua anak) salah satunya adalah akte kelahiran. Syarat membuat akte kelahiran anak adalah buku nikah dan orang yang memiliki buku nikah adalah orang yang ketika melangsungkan akad nikah mencatatkan pernikahannya.

Kata Kunci : Perkawinan, Pernikahan Siri, Undang undang Perkawinan

\section{A. Pendahuluan}

Pengertian perkawinan menurut UUP Pasal 2 ayat (1) yaitu Perkawinan adalah sah bila dilakukan menurut agama dan kepercayaannya itu. Dari sudut pandang aliran positivisme yang mana aliran ini mengutamakan kepastian hukum melalui "hukum adalah undang-undang" maka redaksional pasal ini tidak ada lagi keraguan,semua jelas dan terang benderang bahwa perkawinan adalah sah bila dilakukan menurut agama dan kepercayaannya itu. Sejalan dengan UUP tersebut, Kompilasi Hukum Islam (selanjutnya disingkat KHI) Pasal $4 \mathrm{KHI}^{1}$ memberikan pengertian perkawinan sah adalah sah bila dilakukan menurut hukum Islam sesuai dengan Pasal 2 ayat (1) UUP. ${ }^{2}$

Berdasarkan pasal 6 undang-undang nomor 16 Tahun 2019 tentang Perubahan Atas UU 1 Tahun 1974 tentang Perkawinan, syarat sah sebuah perkawinan diantaranya:

1. Perkawinan harus didasarkan atas persetujuan kedua calon mempelai.

\footnotetext{
${ }^{1}$ Kompilasi Hukum Islam, Inpres. 1 Tahun 1991.

${ }^{2}$ Undang-Undang Perkawinan No. 6 Tahun 2019.
} 
2. Untuk melangsungkan perkawinan seorang yang belum mencapai umur 21 (dua puluh satu) tahun harus mendapat izin kedua orang tua.

3. Dalam hal salah seorang dari kedua orang tua telah meninggal dunia atau dalam keadaan tidak mampu menyatakan kehendaknya, maka izin dimaksud ayat (2) pasal ini cukup diperoleh dari orang tua yang masih hidup atau dari orang tua yang mampu menyatakan kehendaknya.

4. Dalam hal kedua orang tua telah meninggal dunia atau dalam keadaan tidak mampu untuk menyatakan kehendaknya, maka izin diperoleh dari wali, orang yang memelihara atau keluarga yang mempunyai hubungan darah dalam garis keturunan lurus keatas selama mereka masih hidup dan dalam keadaan dapat menyatakan kehendaknya.

5. Dalam hal ada perbedaan pendapat antara orang-orang yang disebut dalam ayat (2), (3) dan (4) pasal ini, atau salah seorang atau lebih diantara mereka tidak menyatakan pendapatnya, maka Pengadilan dalam daerah hukum tempat tinggal orang yang akan melangsungkan perkawinan atas permintaan orang tersebut dapat memberikan izin setelah lebih dahulu mendengar orang-orang tersebut dalam ayat (2), (3) dan (4) pasal ini.

6. Ketentuan tersebut ayat (1) sampai dengan ayat (5) pasal ini berlaku sepanjang hukum masing-masing agamanya dan kepercayaannya itu dari yang bersangkutan tidak menentukan lain.

Menurut Undang-Undang Nomor 16 Tahun 2019 tentang Perubahan Atas UU 1 Tahun 1974 tentang Perkawinan, pengertian perkawinan adalah ikatan lahir batin antara seorang pria dengan seorang wanita sebagai suami isteri dengan tujuan membentuk keluarga (rumah tangga) yang bahagia dan kekal berdasarkan Ketuhanan Yang Maha Esa.

Definisi ini memberikan gambaran bahwa perkawinan adalah suatu ikatan dengan waktu yang kekal, bukan temporer. Selanjutnya Pasal 2 ayat (2) UUP menyatakan bahwa perkawinan dicatatkan menurut perundangan yang berlaku. Pasal ini diperjelas dalam Pasal 5 ayat (1) KHI yaitu:

1. Agar terjamin ketertiban perkawinan bagi masyarakat Islam setiap perkawinan harus dicatat. 
2. Pencatatan perkawinan pada ayat (1) tersebut dilakukan oleh pejabat pencatat perkawinan sesuai undang-undang.

Pasal 5 ayat (1) KHI ini memperjelas bahwa perkawinan harus dicatatkan sesuai Undang-Undang Nomor 22 Tahun 1946 jo UU No.32 Tahun 1954 tentang Pencatatan perkawinan, Talak, dan Rujuk (selanjutnya disingkat (UU PNTR). KHI Pasal 5 tersebut diperjelas lagi dengan ketentuan KHI Pasal 6 yang isinya sebagai berikut:

1. Untuk memenuhi Pasal 5 KHI maka perkawinan harus dilangsungkan di hadapan dan di bawah pengawasan pegawai pencatat perkawinan;

2. Perkawinan yang dilangsungkan di luar pengawasan pegawai pencatat perkawinan tidak mempunyai kekuatan hukum.

Ketentuan KHI Pasal 5 dan KHI Pasal 6 ayat (2) tentang perkawinan ini dengan tegas telah mematahkan konstruksi ketentuan UUP Pasal 2 ayat (1) bahwa perkawinan adalah sah bila dilakukan menurut agama dan kepercayaannya itu dan ketentuan KHI Pasal 4 di mana perkawinana adalah sah bila dilakukan menurut hukum Islam sesuai Pasal 1 ayat (1) jo sesuai Pasal 14 KHI bahwa untuk melaksanakan perkawinan, maka harus ada calon suami, calon isteri, wali perkawinan dan ijab kabul. Penyimpangan terhadap ketentuan UUP Pasal 2 ayat (2) dan KHI Pasal 5 dan Pasal 6 tersebut yang menimbulkan istilah sosial yaitu perkawinan secara agama, ada juga perkawinan yang tidak dicatat, dan perkawinan bawah tangan, ada juga menyebutnya perkawinan siri. Akan tetapi, dalam praktik tidak semua orang dapat menerima peraturan mengenai keharusan pencatatan perkawinan tersebut mengingat berdasarkan sejarah hukum asli perkawinan yang telah turun temurun dilakukan sejak masa nabi Muhammad tidak gampang dihapus dengan pemberian pemahaman positivistik. Paham hukum Islam yang tidak tertulis yang hidup di masyarakat ini sebagian masih kental digunakan.

Nikah dibawah tangan merupakan Pernikahan yang dilaksanakan berdasarkan hukum syariat, tetapi tidak dilakukan di hadapan Petugas Pencatat Nikah (PPN) sebagai aparat resmi pemerintah dan atau tidak dicatatkan di Kantor Urusan Agama (KUA). Sebagaimana disebutkan di dalam pasal 2 ayat (2) 
Undang- Undang No. 1 tahun 1974 yang berbunyi "tiap-tiap perkawinan dicatat menurut peraturan perundang-undangan yang berlaku”. Hal itu tentu memberikan gambaran bagi kita tiap-tiap pernikahan di bawah tangan memiliki kewajiban bagi kedua mempelai untuk mencatatkan perkawinannya di KUA/PPN tempat mereka melangsungkan pernikahan. Dan dengan tidak dilakukannya pencatatan bukan berarti pernikahan yang dilakukan tidak syah secara Islam tetapi tidak sah secara hukum di Indonesia. ${ }^{3}$

Sedangkan KH. Ma'ruf Amin mengatakan bahawa nikah dibawah tangan adalah pernikahan yang terpenuhi semua rukun dan syarat yang ditetapkan dalam fikih (hukum Islam). Namun, nikah ini tanpa pencatatan resmi di instansi berwenang sebagaimana diatur dalam perundang-undangan. ${ }^{4}$

Istilah "tidak dicatat" tidak sama dengan istilah "tidak dicatatkan". Kedua istilah tersebut mengandung makna yang berbeda. Pada istilah "perkawinan tidak dicatat" bermakna bahwa perkawinan itu tidak mengandung unsur "dengan sengaja" yang mengiringi iktikad atau niat seseorang untuk tidak mencatatkan perkawinannya. Adapun istilah "perkawinan tidak dicatatkan" terkandung iktikad atau niat buruk dari suami khususnya yang bermaksud perkawinannya memang "dengan sengaja" tidak dicatatkan. Karena itu penulis menyepadankan "perkawinan tidak dicatat" dengan "perkawinan yang belum dicatatkan" yang berbeda dengan perkawinan tidak dicatatkan. ${ }^{5}$

Kawin siri dianggap sah secara agama Islam oleh masyarakat kebanyakan namun juga dianggap melanggar aturan pemerintah. Namun demikian konsep dan tafsir atas kawin siri tetap mengudara dari waktu ke waktu dan lebih kepada "merahasiakan" suatu perkawinan tertentu. ${ }^{6}$

\footnotetext{
${ }^{3}$ Ahmad, Basyir, Hukum Perkawinan Islam, (Yogyakarta : Kencana, 1977), hlm. 10

${ }^{4}$ Hukum Online, "Nikah dibawah tangan: Pencatatan Nikah Akan Memperjelas Status Hukum". https://www.hukumonline.com/berita/baca/hol15651/pencatatan-nikah-akan-memperjelas-statushukum, diakses pada tanggal 9 Februari 2021.

${ }^{5}$ Neng Djubaidah, Pencatatan Perkawinan dan Perkawinan Tidak Tercatat, (Jakarta : Sinar Garfia, 2010), Hlm. 153

${ }^{6}$ Perkawinan di bawah tangan (Nikah Siri) dalam persfektif feminis oleh Ni'matun Naharin, Nur Fadhilah Forum Perempuan Filsafat, IAIN Tulungagung, dalam file:///C:/Users/user/Downloads/790-Article\%20Text-1676-1-10-20171227.pdf, diakses pada tanggal 9 Februari 2021
} 
Sementara itu pemaknaaan kawin siri dalam ajaran Islam merupakan suatu bentuk substantif yang di dalamnya terdapat kekurangan syarat dan rukun perkawinan meskipun dilihat secara formal itu terpenuhi. Sedangkan dari sisi sosiologisnya masyarakat dalam spektrum perundangan akan dimaknai bahwa setiap perkawinan yang tidak dicatatkan oleh lembaga yang berwenang. ${ }^{7}$ Perkawinan siri ada beberapa macam, di antaranya yaitu perkawinan tanpa wali. Perkawinan semacam ini kadang dilakukan secara rahasia atau siri, sebab wali perempuan mungkin tidak setuju atau mungkin pula karena keabsahan perkawinan dianggap belum terpenuhi.

Mungkin pula hanya demi memuaskan nafsu syahwat sehingga mengindahkan ketentuan syariat-syariat. Perkawinan seperti yang dijelaskan ini jelas sekali sangat tidak sah, sebab wali merupakan rukun sah nikah. ${ }^{8}$ Selanjutnya yaitu perkawinan yang secara agama sah namun tidak kunjung dicatatkan dalam lembaga Negara. Perkawinan ini secara agama sah, akan tetapi dari segi hukum formal atau undang-undang perkawinan tersebut tidak sah. Adapaun fungsi dari pencatatan perkawinan pada lembaga adalah supaya seseorang itu memiliki bukti atau alat bukti untuk digunakan membuktikan bahwa dirinya benar telah melakukan perkawinan dengan orang lain. ${ }^{9}$

Kemudian yang terakhir adalah perkawinan yang sengaja dirahasiakan karena pertimbangan-pertimbangan tertentu. Contohnya, perkawinan yang dilakukan rahasia karena takut memperoleh stereotip dari masyarakat yang sudah terlanjur menganggap suatu perkawinan siri itu tidak baik. Bahkan bisa jadi karena pertimbangan ini memang berbelit-belit sehingga memaksa seseorang untuk merahasiakannya. ${ }^{10}$

Sejak diundangkan Undang-Undang No. 1 tahun 1974, merupakan era baru bagi kepentingan umat Islam khususnya dan masyarakat Indonesia umumya. Undang-undang ini merupakan kodifikasi dan untuk unikasi hukum perkawinan,

\footnotetext{
${ }^{7}$ Thriwaty Arsal, "Nikah Siri dalam Tinjauan Demografi". Jurnal Sosiologi Pedesaan. Vol. 6. No. 2. September 2012. Hlm. 163.

${ }^{8}$ Siti Aminah, "Hukum Nikah di Bawah Tangan (Nikah Siri)", Cendekia Vol 12 Nomor 1 Januari 2014, hlm. 24.

${ }^{9}$ ibid

${ }^{10}$ ibid
} 
yang bersifat Nasional yang menempatkan hukum Islam memiliki eksitensinya sendiri, tanpa harus diresipir oleh hukum adat. Dalam Undang-Undang No. 1 tahun 1974 tentang perkawinan tidak memuat secara tegas pasal yang menjelaskan tentang pernikahan di bawah tangan, akan tetapi hal ini dapat diinterpertasikan dari makna yang tergantung dalam pasal 2 ayat 2 UndangUndang No. 1 tahun 1974 tentang keharusan untuk mencatatkan perkawinan. ${ }^{11}$

Tentang pencatatn perkawinan bagi umat Islam, secara tegas di jelaskan dalam pasal 5 Kompilasi Hukum Islam, yaitu :

1. Agar terjamin ketertiban perkawinan bagi masyarakat Islam, setiap perkawinan harus dicatat.

2. Pencatatn perkawinan tersebut pada ayat (1) dilakukan oleh Pegawai Pencatat Nikah sebagaimana diatur dalam Undang- Undang No. 22 tahun 1946 jo. Undang-Undang No. 32 tahun 1954.

Teknis pelaksanaannya dijelaskan dalam pasal 6 yang menyebutkan:

1. Untuk memenuhi ketentuan pasal 5, setiap perkawinan dilangsungkan di hadapan dan di bawah pengawasan Pegawai Pencatat Nikah.

2. Perkawinan yang dilakukan di luar pengawasan Pegawai Pencatat Nikah tidak mempunyai kekuatan hukum. ${ }^{12}$

Pencatatan perkawinan diatur karena tanpa pencatatan suatu perkawinan tidak mempunyai kekuatan hukum. Akibat yang timbul adalah, apabila salah satu pihak melalaikan kewajibannya, maka pihak lain tidak dapat melakukan upaya hukum, karena tidak memiliki bukti- bukti yang sah dan otentik dari perkawinan yang mereka lakukan

Tentu saja keadaan demikian bertentangan dengan misi dan tujuan perkawinan itu sendiri.8 Secara lebih rinci, Peraturan Pemerintah No. 9 tahun 1975 bab II Pasal 2 menjelaskan tentang pencatatan perkawinan:

1. Pencatatan perkawinan dari mereka yang melangsungkan perkawinan menurut agama Islam, dilakukan oleh Pegawai Pencatat Nikah,

\footnotetext{
${ }^{11}$ Ahmad, Rofiq, Hukum Islam di indonesia, (Jakarta: PT. Raja Grafindo Persada, 1998), hlm. 9

${ }^{12}$ Abdurrahman, Kompilasi Hukum Islam (KHI) pasal 5 ayat $(1,2)$, (Jakarta : 1985). hlm. 21
} 
srbagaimana dimaksudkan dalam UU No. 32 tahun 1954 tentang Pencatat Nikah, Talak, dan Rujuk.

2. Pencatatan Perkawinan mereka yang melangsungkan perkawinan menurut agamanya dan kepercayaannya selain agama Islam, dilakukan oleh Pegawai Pencatat Perkawinan pada Kantor Catatan Sipil sebagaimana dimaksud dalam berbagai perundang-undangan mengenai pencatatn perkawinan.

3. Dengan tidak mengurangi ketentuan-ketentuan yang khusus berlaku bagi tata cara pencatatan perkawinan berdasarkan berbagai peraturan yang berlaku, tata cara pencatatan perkawinan dilakukan sebagaimana ditentukan dalam pasal 2 No. 1 tahun $1974 .^{13}$

Lembaga pencatatan perkawinan merupakan syarat administratif, selain subtansinya bertujuan untuk mewujudkan ketertibab hukum, ia mempunyai cakupan manfaat yang sangat besar bagi kepentingan dan kelangsungan suatu perkawinan. ${ }^{14}$ Pencatatan perkawinan memiliki preventif, yaitu menanggulangi agar tidak terjadi kekurangan atau penyimpangan rukun dan syarat perkawinan, baik menurut hukum agama dan kepercayaanya itu, maupun menurut perundangundangan.

Menurut Abdul Manan, bahwa factor Penyebab mereka melakukan perkawinan di bawah tangan atau secara diam-diam (sirri), antara lain :

1. Pengetahuan terhadap nilai-nilai yang terkandung dalam perkawinan masih sangat kurang peduli menganggap bahwa masalah perkawinan itu adalah masalah pribadi dan tidak perlu ada campur tangan pemerintah/negara.

2. Adanya kekhawatiran dari seseorang akan kehilangan hak pensiun janda apabila perkawinan baru terdaftar pada pejabat pencatat nikah;

3. Tidak ada izin dari istrinya dan Pengadilan Agama bagi orang yang bermaksud kawin lebih dari satu orang;

\footnotetext{
13 Hasbullah, Bakhry, Kumpulan Lengkap Udang-Undang dan Peraturan Perkawinan di Indonesia, (Jakarta : Djambatan, 1985), Cet. III, hlm. 34

${ }^{14}$ Ahmad Rofiq, Op.,cit., hlm. 11
} 
4. Adanya kekhawatiran orang tua terhadap anaknya yang sudah bergaul rapat dengan calon istri/suami, sehingga dikhawatirkan terjadi hal-hal negatif yang tidak diinginkan, kemudian dikawinkan secara diam-diam.

5. Adanya kekhawatiran orang tua yang berlebihan terhadap jodoh anaknya, karena anaknya segera dikawinkan dengan suatu harapan pada suatu saat jika sudah mencapai batas umur yang ditentukan terpenuhi, maka perkawinan baru dilaksanakan sesuai dengan ketentuan yang telah ditetapkan. $^{15}$

Perkawinan di bawah tangan merupakan bentuk perkawinan yang telah merupakan mode masa kini yang timbul dan berkembang diam-diam pada sebagian masyarakat Islam Indonesia. Mereka berusaha menghindari diri dari sistem dan cara pengaturan pelaksanaan perkawinan menurut Undang-undang Nomor 1 Tahun 1974, yang birokratis dan berbelit-belit serta lama pengurusannya atau secara sengaja merahasiakan perkawinan karena poligami. Untuk itu mereka menempuh cara sendiri yang tidak bertentangan dengan Hukum Islam. Dalam ilmu hukum cara seperti itu dikenal dengan istilah 'Penyelundupan Hukum" yaitu suatu cara untuk menghindari diri dari persyaratan hukum yang ditentukan oleh Undang-undang dan peraturan yang berlaku dengan tujuan perbuatan bersangkutan, dapat menghindarkan suatu akibat hukum yang tidak dikehendaki atau untuk mewujudkan suatu akibat hukum dikehendaki. ${ }^{16}$

Pernikahan siri atau pernikahan di bawah tangan ialah pernikahan yang dilaksanakan dengan tidak memenuhi syarat dan prosedur peraturan perundangan. Menurut hukum islam, pernikahan siri adalah sah, asalkan terpenuhi syarat rukun perkawinan. Namun dari aspek peraturan perundang-undangan perkawinan model ini belum lengkap dikarenakan belum dicatatkan. 12 Nikah siri secara istilah adalah pernikahan yang rukun dan syaratnya terpenuhi, namun dilakukan secara rahasia dan umumnya tanpa dicatatkan dalam pencatatan badan yang berwenang disuatu negara. ${ }^{17}$

\footnotetext{
15 Abdul Manan. 2006. Aneka MasalahHukumPerdata Islam di Indoensia.Jakarta:Kencana. Hlm 47-48

${ }^{16}$ Gouw Giok Siong. 1964. Hukum Perdata Internasional Indonesia. Jakarta : PT Kinta. Hlm 20

${ }^{17}$ Luthfi, Musthafa, and Mulyadi Luthfy. Nikah Sirri. Surakarta: Wacana Ilmiah Press, 2010
} 
Menurut Jaih Mubarok, pada umumnya yang dimaksud perkawinan tidak tercatat adalah perkawinan yang tidak dicatat oleh PPN (Pegawai Pencatat Nikah) atau perkawinan yang dilakukan oleh orang-orang Islam di Indonesia, memenuhi baik rukun-rukun maupun syaratsyarat perkawinan. Sebaliknya perkawinan tercatat adalah perkawinan yang dicatat oleh PPN. Perkawinan yang tidak berada di bawah pengawasan PPN, dianggap sah secara agama tetapi tidak mempunyai kekuatan hukum karena tidak memiliki bukti-bukti perkawinan yang sah menurut Peraturan Perundang-Undangan yang berlaku. ${ }^{18}$

Pengertian yang sama dikemukakan Idris Ramulyo, yang dimaksud perkawinan tidak tercatat adalah suatu perkawinan yang dilakukan oleh orangorang Islam Indonesia, memenuhi baik rukun-rukun maupun syarat-syarat perkawinan, tetapi tidak didaftarkan pada Pejabat Pencatat Nikah. ${ }^{19}$

\section{B. Hasil Penelitian dan Pembahasan}

\section{Akibat hukum dari perkawinan di bawah tangan}

Akibat hukum dari perkawinan di bawah tangan, meski secara agama atau kepercayaan dianggap sah, namun perkawinan yang dilakukan di luar pengetahuan dan pengawasan pegawai pencatat nikah tidak memiliki kekuatan hukum yang tetap dan dianggap tidak sah di mata hukum Negara. Akibat hukum perkawinan tersebut berdampak sangat merugikan diantaranya bagi anak yang dilahirkan. Sebagaimana pendapat Ali Uraidy mengungkapkan akibat-akibat hukum dari perkawinan sirri diantaranya: ${ }^{20}$

a. Tidak adanya kekuatan hukum yang tetap terhadap legalitas perkawinan tersebut, sehingga apabila adanya hak-hak istri yang dilanggar oleh suami, istri tidak dapat menuntut hak-hak tersebut secara hukum;

b. Akad nikah yang dilakukan cenderung tidak dapat dibuktikan secara hukum dan suami istri yang melaksanakan akad nikah sirri tidak dapat

\footnotetext{
18 Jaih Mubarok. Modernisasi Hukum Perkawinan Di Indonesia. Pustaka Bani Quraisy, 2005, hlm. 87

${ }^{19}$ Ramulyo, Tinjauan Beberapa Pasal Undang-Undang Nomor 1 Tahun 1974 Dari Segi Hukum Perkawinan Islam.

${ }^{20}$ Drs. Ali Uraidy, M.H., ${ }^{3}$ Pekawinan Sirri dan Akibat Hukumnya Ditinjau Dari UndangUndang No. 1 Tahun 1974¥, Jurnal Ilmiah FENOMENA, Volume X, Nomor 2, November 2012, hal. 990.
} 
membuktikan bahwa keduanya merupakan pasangan yang legal dimata hukum Islam maupun Negara. Kendati adanya saksi, namun karena usia adalah terbatas, sehingga tidak bisa lagi menjadi saksi ketika diperlukan. Selain itu, kita bisa saja hidup berpindah-pindah ke tempat dan daerah lain, sehingga ketika diperlukan adanya bukti pernikahan tersebut, suami istri akad nikah sirri tidak mungkin menghadirkan saksi tersebut;

c. Kepentingan-kepentingan suami istri lainnya dalam menjalani kehidupan berumah tangga tidak dapat dilindungi;

d. Karena tidak ada bukti adanya perkawinan tersebut, kepentingan seperti terkait dengan pembuatan Kartu Tanda Penduduk (KTP), Kartu Keluarga (KK), Pasport, Akta kelahiran anak atau pun berkaitan dengan politik yaitu berhaknya memberikan suara atau dipilih pada pemilihan umum tidak dapat dilayani. Semua itu karena tidak adanya bukti pernikahan berupa Akta Nikah/Buku Nikah yang akhirnya tidak dapat membuat KTP dan Kartu Keluarga, sementara untuk membuat akte kelahiran anak, atau passport diharuskan adanya KTP, KK dan buku nikah.

e. Akad nikah sirri cenderung membuat salah satu pasangan, khususnya suami lebih leluasa untuk meninggalkan kewajibannya, bahkan memperlakukan istrinya dengan kekerasan;

f. Akad nikah sirri berakibat mengganggu kemaslahatan agama, ajaran agama cenderung dipraktekakan secara kacau. Kekacauan tersebut dapat digambarkan bahwa apabila suatu akad nikah tidak dicatat secara resmi di hadapan pejabat yang berkewenangan yakni, Pegawai Pencatat Nikah, maka akad nikah seperti ini cenderung tidak dapat dikontrol. Akhirnya dapat membuka peluang pada suami untuk melakukan akad nikah kembali dengan perempuan lain tanpa terlebih dahulu mendapatkan persetujuan secara resmi dari istri pertama melalui proses persidangan. Perilaku seperti ini cenderung akan terualang kembali sampai akhirnya suami pun berpotensi memiliki istri melebihi dari ketentuan agama. Akhirnya kemaslahatan agama juga ikut terganggu dengan perilaku seperti yang digambarkan; 
g. Akad nikah sirri dapat berakibat mempengaruhi kemaslahatan psikologis istri dan anak, mereka pun merasa tidak nyaman dan tidak tenang. Terlebih ketika anak memasuki usia sekolah dan ketika didaftarkan, setiap lembaga pendidikan selalu mensyaratkan kepada pendaftar (orang tua anak) salah satunya adalah akte kelahiran. Syarat untuk membuat akte kelahiran anak adalah buku nikah dan orang yang memiliki buku nikah adalah orang yang ketika melangsungkan akad nikah mencatatkan pernikahannya. Apabila buku nikah tidak dimiliki, akte kelahiran pun tidak dapat diberikan karena bukti hukum untuk menyatakan bahwa seorang anak tersebut adalah anak sah pasangan suami istri yang ingin membuat akte kelahiran anaknya tersebut tidak dimiliki.

h. Akad nikah sirri dapat berakibat mempengaruhi kemaslahatan akal. Dikatakan demikian karena dengan adanya rasa tidak nyaman bahkan hilangnya rasa percaya diri disebabkan orang tuanya tidak memiliki buku nikah, anak pun tidak dapat berpikir dengan baik. Artinya dengan kondisi psikologis yang tidak nyaman karena merasa keberadaannya sebagai aib dalam kehidupan manusia sehingga dapat berakibat hilangnya rasa percaya diri. Anak itu pun akhirnya mulai menghindari untuk bergaul dan lebih memilih untuk mengurung diri di rumah;

i. Akad nikah sirri dapat berakibat mempengaruhi kemaslahatan keturunan. Dikatakan demikian karena dengan tidak tercatatnya akad nikah, anak yang dilahirkan pun tidak memiliki identitas yang jelas asal usul yang dapat dibuktikan secara hukum, sehingga cenderung dianggap orang sebagai anak hasil hubungan yang tidak sah;

j. Akad nikah sirri dapat berakibat mempengaruhi kemaslahatan harta. Disebut demikian karena tidak jelasnya identitas pernikahan dan pernikahan pun tidak dapat dibuktikan melalui buku nikah, maka identitas anak yang dilahirkan juga tidak jelas, sehingga ketika orang tuanya meninggal, anak mendapatkan kesulitan untuk mendapatkan harta waris dari orang tuanya, termasuk pula istri akibat akad nikah sirri ini, dia pun 
mendapatkan kesulitan untuk menyatakan dirinya sebagai ahli waris yang sah, baik sebagai istri pertama atau sebagai istri yang kedua dan seterusnya. Itulah beberapa akibat dari akad nikah sirri, walaupun akad nikah sirri dipandang sebagai akad nikah yang sah, asalkan terpenuhi rukun dan syaratnya, tetapi akibat yang timbul dari akad nikah sirri, lebih besar kemudaratannya daripada kemaslahatannya. ${ }^{21}$ Selain pendapat diatas, menurut Abdul Manan, bahwa dampak perkawinan yang tidak dicatat antara lain: ${ }^{22}$

1. Suami istri tersebut tidak mempunyai akta nikah sebagai bukti mereka telah menikah secara sah menurut agama dan negara,

2. Anak-anak tidak dapat memperoleh akta kelahiran dari istri yang berwenang karena untuk mendapatkan akta kelahiran itu diperlukan akta nikah dari orang tuanya,

3. Anak-anak tidak dapat mewarisi harta orang tuanya karena tidak ada bukti autentik yang menyatakan mereka sebagai ahli waris orang tuanya,

4. Tidak memperoleh hak-hak lainnya dalam pelaksanaan administrasi negara yang mesti harus dipenuhi sebagai bukti diri.

\section{Dasar Pertimbangan Majelis Hakim dalam memutuskan perkara nomor 40/Pdt.P/2018/PA.Wsb}

\section{a. Duduk Perkara}

Tepatnya pada tanggal 24 Mei tahun 2013 Pemohon I telah melangsungkan pernikahan dengan Pemohon II secara secara Hukum Munakahat Islam, dengan wali nikah nama ayah (ayah kandung Pemohon II) dengan maskawin seperangkat alat sholat yang dibayar tunai, akad nikah tersebut disaksikan oleh 2 (dua) orang saksi masing-masing bernama Dedi Santosa dan Nanang. Pelaksanaan akad nikah dilangsungkan pada sekitar pukul 14.00 WIB bertempat di kediaman nama kyai di, Kabupaten Banyumas, yang pada saat itu acara terbatas dihadiri dari keluarga dan teman

\footnotetext{
${ }^{21}$ http://registrasi.seminar.uir.ac.id/prosiding/sem_nas17/file/SOC01704_Anton\%20Afrizal\%20C handra.pdf

${ }^{22}$ Abdul Manan. 2006. Aneka MasalahHukumPerdata Islam di Indoensia.Jakarta:Kencana. Hlm $47-48$
} 
dekat. Pada saat akad nikah dilangsungkan, untuk ijabnya Ayah Kandung Pemohon II yang bernama nama ayah selaku wali nikah, mewakilkan (pasrah wali) kepada nama Kyai dan kabulnya dilakukan sendiri oleh Pemohon I selaku mempelai pria dalam satu majelis (ittihad al-majlis).

Pernikahan secara Hukum Munakahat Islam tersebut atas kehendak Pemohon I dan Pemohon II sendiri, direstui oleh orangtua kedua belah pihak, antara Pemohon I dengan Pemohon II tidak ada hubungan darah, tidak sesusuan, tidak terikat dengan hubungan pernikahan yang lain serta memenuhi syarat dan/ atau tidak ada larangan untuk melangsungkan pernikahan menurut ketentuan hukum Islam.Pemohon I dan Pemohon II melakukan nikah secara secara Hukum Munakahat Islam dengan pertimbangan:

1. Pemohon I masih kuliah begitu juga Pemohon II masih kuliah namun hubungan keduanya sudah sedemikian eratnya sehingga sangat khawatir dapat terjerumus dalam perbuatan yang dilarang oleh Syariat Islam, sementara dari Kampus dimana kuliah menghimbau selama kuliah mahasiswa tidak menikah dan/ atauhamil,

2. Ayah kandung Pemohon II menganjurkan untuk menikah secara agama untuk menghindari perbuatan maksiat dan menolak fitnah,

3. Pemohon I belum mempunyai pekerjaan tetap, kondisi keuangan keluarga waktu itu juga belum memungkinkan untuk mengadakan walimah pernikahan ;

Setelah pernikahan, Pemohon I dan Pemohon II telah hidup sebagaimana layaknya suami isteri tinggal bersama satu rumah bertempat di, Kabupaten Wonosobo sampai dengan sekarang dan tidak pernah bercerai dan tidak pernah keluar dari Agama Islam. Dalam masa pernikahan Para Pemohon secara Hukum Munakahat Islam sebagaimana tersebut diatas, pada tanggal 24 Mei 2014 Pemohon II telah melahirkan seorang anak berjenis kelamin laki-laki yang diberi nama nama anak. Kemudian pada tanggal 15 April 2016 Pemohon I dan Pemohon II telah menikah ulang yang dicatat oleh Pegawai Pencatat Nikah Kantor Urusan Agama (KUA), Kabupaten 
Wonosobo sebagaimana dalam Kutipan Akta Nikah Nomor : akta nikah tertanggal 15 April 2016.

Pada sekitar bulan Juli 2016 Para Pemohon telah mengurus dokumen Akta Kelahiran untuk anak yang bernama nama anak tersebut dan setelah dilakukan pengurusan terbitlah Kutipan Akta Kelahiran Nomor : akta anak yang dikeluarkan oleh Kantor Adminduk dan Pencatatan Sipil Kabupaten Wonosobo tertanggal 28 Juli 2016, dalam dokumen Akta Kelahiran tersebut hanya nama Pemohon II (ibu) yang tercantum sebagai orangtuanya. Para Pemohon mengakui bahwa anak yang bernama Nama anak, jenis kelamin laki-laki, lahir di Wonosobo pada tanggal 24 Mei 2014 adalah benar-benar anak dari hasil hubungan Pemohon I dan Pemohon II dalam ikatan pernikahan yang sah secara hukum munakahat Islam, sehingga anak tersebut mempunyai hubungan nasab dan keperdataan dengan Pemohon I. Anak tersebut tidak pernah diakui oleh orang lain (pihak ketiga) sebagai anaknya dan sejak lahir hingga saat ini dirawat dan diasuh secara bersama oleh Pemohon I dan Pemohon II.

Selanjutnya Para Pemohon ingin memperoleh kepastian hukum terhadap anak kandung tersebut diatas sebagai anak dari Para Pemohon, karenanya memiliki hubungan nasab dan keperdataan dengan Pemohon I sebagai ayahnya tidak hanya kepada Pemohon II (ibunya) saja. Kepastian hukum terhadap anak dimaksud juga diperlukan untuk pelaporan mengenai anak kandung pada Kantor Administrasi Kependudukan dan Pencatatan Sipil Kabupaten Wonosobo. Berkaitan dengan perkara ini, terdapat putusan Pengadilan Agama Yogyakarta Nomor : 0045/Pdt.P/2010/PA.Yk., tanggal 19 Oktober 2010 yang pada intinya mengabulkan permohonan pengesahan/ pengakuan anak yang lahir dalam pernikahan yang sah sesuai dengan hukum munakahat islam

\section{b. Pertimbangan Majelis Hakim}

Berdasarkan fakta-fakta yang ada, Majelis Hakim berpendapat akad nikah yang dilaksanakan oleh Para Pemohon pada tanggal 24 Mei 2013 di Rumah Nama Kyai di Banyumas telah memenuhi ketentuan yang termuat 
dalam Pasal 14 Kompilasi Hukum Islam serta tidak melanggar larangan Kawin sebagai mana yang termuat dalam pasal 39 sampai dengan Pasal 44 Kompilasi Hukum Islam sehingga akad nikah tersebut sah menurut agama Islam.

Selain itu dari perkawinan para pemohon tersebut telah lahir seorang anak yang diberi nama NAMA ANAK lahir pada tanggal 24 Mei tahun 2014 maka oleh karena anak tersebut lahir akibat dari perkawinan yang sah antara pemohon I dan pemohon II maka berdasarkan pasal 99 huruf a Kompilasi Hukum Islam anak yang dilahirkannya pun, dalam hal ini anak yang diberi nama NAMA ANAK lahir pada tanggal 24 Mei tahun 2014, adalah anak sah Pemohon I dan Pemohon II. Dan berdasarkan pertimbangan tersebut diatas, permohonan para Pemohon dalam petitum nomor 2 patut dikabulkan.

Dalam pertimbangan lain, bahwa para Pemohon juga memohon supaya NAMA ANAK lahir pada tanggal 24 Mei tahun 2014, bernasabkan kepada Pemohon I dan Pemohon II bukan hanya kepada ibunya (pemohon II) sebagaimana tertulis dalam bukti P.5, maka untuk kepentingan anak tersebut dan dampak psikologis anak dimasa yang akan datang, Majelis Hakim berpendapat karena hal ini merupakan peristiwa penting sebagaimana pasal 1 ayat 17 dan Pasal 49 Undang-Undang Nomor 24 Tahun 2013 Tentang Perubahan Atas Undang-Undang Nomor 23 Tahun 2006 Tentang Administrasi Kependudukan dalam hal ini adanya pengakuan anak oleh Pemohon I serta adanya penetapan anak NAMA ANAK sebagai anak sah Pemohon I dan. Pemohon II dalam uraian diatas maka kepada Para Pemohon diperintahkan untuk melaporkan penetapan ini kepada Kantor Administrasi Kependudukan dan Pencatatan Sipil Kabupaten Wonosobo untuk dicatat dalam daftar yang diperuntukkan untuk itu. Menimbang, bahwa berdasarkan pertimbangan tersebut Majelis Hakim dapat mengabulkan permohonan para pemohon dalam petitum 3;

Dan bahwa perkara ini, perkara volunter dan masih dalam ruang lingkup masalah perkawinan maka maka berdasarkan Pasal 89 ayat Undangundang Nomor 7 Tahun 1989 sebagaimana telah diubah dengan Undang- 
undang Nomor 3 Tahun 2006 dan perubahan kedua dengan Undang-undang Nomor 50 Tahun 2009, biaya perkara dibebankan kepada Pemohon yang besarnya sebagaimana tercantum dalam amar penetapan ini.

\section{c. Analisis}

Dalam sistem hukum Indonesia yang berlaku, nikah siri tidak diakui oleh negara kita. Hal itu disebabkan karena dalam peraturan perundang-undangan dan ketentuang yang ada, tidak ada yang mengatur secara eksplisit tentang pernikahan siri. Pernikahan hanya diakui oleh negara apabila mengikuti ketentuan UndangUndang Nomor 1 Tahun 1974 sebagai mana yang telah diubah menjadi UndangUndang Nomor 16 Tahun 2019 Tentang Perkawinan.

Penikahan siri tidak diakui karena pernikahan tersebut tidak tercatat tentu hal ini bertentangan dengan Pasal 2 ayat (2) Undang-Undang Nomor 1 Tahun 1974 sebagai mana yang telah diubah menjadi Undang-Undang Nomor 16 Tahun 2019 Tentang Perubahan Atas UndangUndang Nomor 1 Tahun 1974 Tentang Perkawinan yang menyebutkan bahwa "Tiap-Tiap Perkawinan dicatat menurut peraturan perundang-undangan yang berlaku" Pada Undang-Undang perkawinan ketentuan Pasal 2 ayat (1) yang berbunyi "Perkawinan adalah sah apabila dilakukan menurut hukum masing-masing agama dan kepercayaannya itu”.

Dan dalam Pasal 2 ayat (2) yang berbunyi "Tiap-tiap perkawinan dicatat menurut peraturan perundang-undangan yang berlaku". Dari pasal 2 UndangUndang perkawinan tersebut masyarakat hanya menerapkan Pasal 2 ayat (1) tetapi tidak menerapkan Pasal 2 ayat (2).

\section{Penutup}

Status perkawinan dibawah tangan ditinjau dari Hukum Islam adalah sah apabila memenuhi rukun dan semua syarat sahnya nikah meskipun tidak dicatatkan. Menurut ketentuan pada Pasal 2 Ayat (1) UU Perkawinan, sebuah perkawinan adalah sah apabila dilakukan menurut hukum masing-masing agamanya dan kepercayaannya itu selama memenuhi syarat dan rukun nikah. Namun sahnya perkawinan ini di mata agama dan kepercayaan masyarakat perlu dipastikan lagi oleh negara, yang dalam hal ini ketentuannya terdapat pada 2 ayat 
(2) Undang-Undang Nomor 1 Tahun 1974 sebagai mana yang telah diubah menjadi Undang-Undang Nomor 16 Tahun 2019 Tentang Perubahan Atas UndangUndang Nomor 1 Tahun 1974 Tentang Perkawinan.

Akibat hukum dari perkawinan di bawah tangan, meski secara agama atau kepercayaan dianggap sah, namun perkawinan yang dilakukan di luar pengetahuan dan pengawasan pegawai pencatat nikah tidak memiliki kekuatan hukum yang tetap dan dianggap tidak sah di mata hukum negara. Akibat hukum perkawinan tersebut salah satunya berakibat mempengaruhi kemaslahatan psikologis istri dan anak, mereka pun merasa tidak nyaman dan tidak tenang. Terlebih ketika anak memasuki usia sekolah dan ketika didaftarkan, setiap lembaga pendidikan selalu mensyaratkan kepada pendaftar (orang tua anak) salah satunya adalah akte kelahiran. Syarat untuk membuat akte kelahiran anak adalah buku nikah dan orang yang memiliki buku nikah adalah orang yang ketika melangsungkan akad nikah mencatatkan pernikahannya. Apabila buku nikah tidak dimiliki, akte kelahiran pun tidak dapat diberikan karena bukti hukum untuk menyatakan bahwa seorang anak tersebut adalah anak sah pasangan suami istri yang ingin membuat akte kelahiran anaknya tersebut tidak dimiliki

\section{Daftar Pustaka}

Abdurrahman, Kompilasi Hukum Islam (KHI) pasal 5 ayat (1,2), (Jakarta : 1985) Ahmad, Basyir, Hukum Perkawinan Islam, (Yogyakarta: Kencana, 1977)

Abdul Manan. 2006. Aneka MasalahHukumPerdata Islam di Indoensia.Jakarta: Kencana

Abdul Manan. 2006. Aneka MasalahHukumPerdata Islam di Indoensia.Jakarta: Kencana

Ahmad,Rofiq, Hukum Islam di Indonesia, (Jakarta: PT. Raja Grafindo Persada, 1998)

Ali Uraidy, M.H., ${ }^{3}$ Pekawinan Sirri dan Akibat Hukumnya Ditinjau Dari UndangUndang No. 1 Tahun 1974¥, Jurnal Ilmiah FENOMENA, Volume X, Nomor 2, November 2012, http://registrasi.seminar.uir.ac.id/prosiding/sem_nas17/file/SOC01704_Anto n\%20Afrizal\%20Chandra.pdf

Gouw Giok Siong. 1964. Hukum Perdata Internasional Indonesia. Jakarta : PT Kinta

Hasbullah, Bakhry, Kumpulan Lengkap Udang-Undang dan Peraturan Perkawinan di Indonesia, (Jakarta: Djambatan, 1985), Cet. III

Hukum Online, “Nikah dibawah tangan: Pencatatan Nikah Akan Memperjelas 


\section{Status}

Hukum". https://www.hukumonline.com/berita/baca/hol15651/pencatatan-nikah-akanmemperjelas-status-hukum, diakses pada tanggal 23 Agustus 2021.

Jaih Mubarok. Modernisasi Hukum Perkawinan Di Indonesia. Pustaka Bani Quraisy, 2005

Kompilasi Hukum Islam, Inpres. 1 Tahun 1991.

Luthfi Musthafa, and Mulyadi Luthfy. Nikah Sirri. Surakarta: Wacana Ilmiah Press, 2010

Neng Djubaidah, Pencatatan Perkawinan dan Perkawinan Tidak Tercatat, (Jakarta : Sinar Garfia, 2010),

Perkawinan di bawah tangan (Nikah Siri) dalam persfektif feminis oleh Ni'matun Naharin, Nur Fadhilah Forum Perempuan Filsafat, IAIN Tulungagung, dalam file:///C:/Users/user/Downloads/790-Article\%20Text-1676-1-1020171227.pdf, diakses pada tanggal 23 Agustus 2021

Ramulyo, Tinjauan Beberapa Pasal Undang-Undang Nomor 1 Tahun 1974 Dari Segi Hukum Perkawinan Islam.

Rony Hanitidjo Soemitro, Metodologi Penelitian Hukum dan Jurimetri

Siti Aminah, "Hukum Nikah di Bawah Tangan (Nikah Siri)", Cendekia Vol 12 Nomor 1 Januari 2014

Soerjono Soekanto dkk,. Pengantar Penelitian Hukum, 1984

Thriwaty Arsal, "Nikah Siri dalam Tinjauan Demografi". Jurnal Sosiologi Pedesaan. Vol. 6. No. 2. September 2012

Undang-Undang Perkawinan No. 6 Tahun 2019. 